\title{
PKA-dependent Regulation of mKv1.1, a Mouse Shaker-like Potassium Channel Gene, When Stably Expressed in CHO Cells
}

\author{
Martha M. Bosma, Margaret L. Allen, Troy M. Martin, and Bruce L Tempel \\ Geriatric Research Education and Clinical Center, VA Medical Center, Seattle, Washington 98108, and the Departments \\ of Medicine and Pharmacology, University of Washington School of Medicine, Seattle, Washington 98195
}

Potassium (K) channels are important regulators of cellular physiology and can themselves be modulated by phosphorylation. We have investigated the potential protein kinase A (PKA) regulation of mKv1.1, a mouse Shaker-like $K$ channel gene, when it is expressed in stably transfected Chinese hamster ovary (CHO) cell lines. Whole-cell patchclamp records show that expression of mKv1.1 gives rise to a rapidly activating, sustained $K+$ current, referred to classically as a delayed rectifier-type current. In order to study the effects of PKA, we compared cell lines transfected with mKv1.1 alone with lines cotransfected with both mKv1.1 and a plasmid encoding a dominant negative mutation in the regulatory subunit of PKA. These mutant regulatory subunits bind to endogenous catalytic subunits of PKA but do not respond to CAMP, thereby causing a chronic reduction in the basal PKA activity in these cells. We found that mKv1.1 current kinetics are unaltered but current density is 3.4-fold higher in the cell lines expressing mutant regulatory subunit than in lines expressing only $\mathrm{mKv1.1}$. RNase protection assays indicate that levels of the specific RNA for mKv1.1 are increased almost twofold in the lines expressing mutant regulatory subunit over the lines expressing mKv1.1 only. Further, the levels of $\mathrm{mKv} 1.1$ protein, assayed using an $\mathrm{mKv} 1.1$ channel-specific antibody, are increased by almost a factor of 3 between the two types of cell lines. These results suggest that PKA can regulate mKv1.1 channel expression by changing steady-state levels of RNA and by other posttranscriptional mechanisms.

IKey words: potassium channel, delayed rectifier, phosphorylation, protein kinase A, channel regulation, gene expression]

Voltage-gated potassium channels are a diverse family of structurally related proteins, each with unique kinetics, pharmacology, and tissue distribution. Molecular cloning and expression of a number of $\mathrm{K}$ channel genes have provided new insight into channel structure and the functions of various domains of the channel (Miller, 1991). Relatively little is known, however, about the mechanisms regulating $\mathrm{K}$ channel gene expression or those

\footnotetext{
Received July 8, 1992; revised May 24, 1993; accepted June 17, 1993.

We thank W. Hopkins, C. Olsson, and G. S. McKnight for comments on the manuscript, and J. West, W. Catterall, and G. S. McKnight for the RevAB- CHO cell line. This work was supported by a fellowship from the Mellon Foundation (M.M.B.) and grants from the NIH (NS-27206 and HL-44948 to B.L.T.).

Correspondence should be addressed to B. L Tempel, 182-B, VA Medical Center, Seattle, Washington 98108.

Copyright (C) 1993 Society for Neuroscience $0270-6474 / 93 / 135242-09 \$ 05.00 / 0$
}

regulating assembly, distribution, and stability of the channel proteins. These processes are likely to be important in determining the contribution of each channel type to the various $\mathrm{K}^{+}$ currents measured in cells where each gene is expressed.

The first mammalian $\mathrm{K}$ channel genes were isolated from mouse brain (Tempel et al., 1988) and from rat brain (Baumann et al., 1988) based on the similarity of these genes to the Drosophila Shaker K channel genes (Jan and Jan, 1989; Salkoff et al., 1992). Recently, these genes have been designated Kvl.1 to indicate their ionic selectivity, voltage sensitivity, subfamily membership, and order of isolation (Chandy et al., 1991). Functional expression of the rat brain clone in Xenopus oocytes and in stably transfected mammalian Sol 8 cells demonstrated that rKv1.1 (previously RCK1) currents were rapidly activating, with inactivation over tens of seconds (Stuehmer et al., 1988; Christie et al., 1989; Koren et al., 1990). Similar kinetics are observed when mKv1.1 (previously referred to as MBK1) is expressed in Xenopus oocytes (Hopkins and Tempel, 1992). The Kvl.1 gene sequences from all mammalian species studied to date predict a consensus PKA phosphorylation site in the carboxyl end of the channel subunit. Similar sites are observed in other related K channels (Chandy et al., 1990; Drewe et al., 1992).

A large body of work has demonstrated that kinase activity, in particular protein kinase A (PKA) activity, is important in gene regulation, development, learning, and at times when the nervous system undergoes plastic remodeling (Montminy et al., 1989; Mayford et al., 1992). However, fewer studies have reported on the regulation of expression of ion channels. Modulation of $\mathrm{Ca}$ channels by hormone action in cardiac tissue has been shown to upregulate current by direct $\mathrm{PK} \Lambda$-mediated phosphorylation of the channel (Trautwein and Hescheler, 1990). In stably transfected $\mathrm{CHO}$ cells expressing $\mathrm{Na}$ channel cDNA, acute stimulation of PKA activity suppresses $\mathrm{Na}^{+}$current. Removal of basal PKA activity in those cells upregulates channel expression by a posttranscriptional mechanism (Li et al., 1992). In contrast, during NGF-mediated PC1 2 cell differentiation, the endogenous $\mathrm{Na}^{+}$current is upregulated by cAMP stimulation via a pathway that requires a functional PKA catalytic subunit (Kalman et al., 1990). Reduction of basal PKA activity in this system blocks functional $\mathrm{Na}$ channel expression although $\mathrm{Na}$ channel transcript is upregulated (Ginty et al,, 1992).

Physiological evidence suggests that voltage-gated $\mathrm{K}$ channels are also modulated by hormones in many tissues. Indeed, PKA modulation of delayed rectifier-type $\mathrm{K}^{+}$currents has been shown clearly in heart and in lymphocytes (Giles et al., 1989; Soliven and Nelson, 1990). In cardiac tissue, however, the molecular species of $\mathrm{K}$ channel(s) modulated by PKA is not known since several different $K$ channel genes with potential PKA phos- 
phorylation sites are expressed in cardiac tissue (Roberds and Tamkun, 1991). In addition, a unique, small $\mathrm{K}$ channel gene that is expressed in heart and involved in the establishment of a slowly activating $\mathrm{K}^{+}$current, $I_{\mathrm{sK}}$, has been shown to be modulated by PKA-induced insertion of channels into the membrane of the Xenopus oocyte expression system (Blumenthal and Kaczmariek, 1992).

Here we address the question of PKA regulation of the expression of a cloned $\mathrm{K}$ channel cDNA, mKvl.1, by using a molecular tool to block endogenous PKA activity. We have stably transfected $\mathrm{mKv} 1.1$ into $\mathrm{CHO}$ cells, and also into $\mathrm{CHO}$ cells that contain a plasmid encoding a dominant mutant regulatory subunit of PKA (Clegg et al., 1987). This PKA regulatory subunit has been mutated in both the $A$ and $B$ cAMP binding sites $\left(\mathrm{AB}^{-}\right)$, and therefore remains constitutively bound to the catalytic subunit of PKA, inactivating the endogenous PKA. We have used this model to study the effects of PKA on expression of mKv1.1 RNA, protein, and current. Our results suggest that reducing basal PKA activity leads to an increase in $\mathrm{mKv} 1.1 \mathrm{~K}^{+}$ current via an increase in RNA as well as other posttranscriptional mechanisms.

\section{Materials and Methods}

Plasmids. For establishment of the stable cell lines, a fragment of the mKv1.1 potassium channel cDNA clone MK9.6 (Tempel et al., 1988) was inserted into the BamHI restriction endonuclease site of pZEM 228 (kindly provided by E. Mulvihill, Zymogenetics Inc., Seattle, WA). The subcloned region of mKv1.1 extends from the SmaI site 40 base pairs (bp) upstream of the AUG start codon through the HindIII site downstream from the TAA stop codon. Thus, in this pZEM-mKv1.1 construct, the coding region of mKv1.1 is placed downstream of a mouse metallothionine promoter with high constitutive activity and upstream of SV40 polyadenylation and termination sequences. In order to generate riboprobes that protect the $5^{\prime}$ end of the $\mathrm{mKv} 1.1$ sequence, a 252 bp fragment from the SmaI site to the SphI site, encompassing the AUG start codon, was cloned into pBlucscript SK + (Strategene, La Jolla, CA). For riboprobes that protect the $3^{\prime}$ end of the $\mathrm{mKvl} 1.1$ sequence, a 197 bp fragment from BclI to HindIII, including the TAA stop codon, was cloned into pBluescript $\mathrm{SK}^{+}$(see Fig. $5 B$ ).

Cell culture and transfection. Wild-type $\mathrm{CHO}$ cells were maintained using standard tissue culture techniques in RPMI 1640 medium supplemented with $5 \%$ fetal bovine serum, $2 \mathrm{~mm}$ glutamine, $50 \mathrm{U}$ of penicillin $/ \mathrm{ml}$, and $50 \mu \mathrm{g}$ of streptomycin $/ \mathrm{ml}$. $\mathrm{CHO} / \mathrm{AB}^{-}$cells containing the mutant regulatory subunit of PKA (kindly provided by the laboratory of Dr. William Catterall, University of Washington) were maintained with the same medium supplemented with $200 \mu \mathrm{g} / \mathrm{ml}$ hygromycin. Both lines of $\mathrm{CHO}$ cells were transfected with $15 \mu \mathrm{g}$ of $\mathrm{pZEM}-$ mKv1.1 plasmid DNA by electroporation using a Bio-Rad Gene Pulser Transfection Apparatus (Richmond, CA). Two days after the transfection procedure, G418 (Gencticin, GIBCO-Bethesda Research Labs, Gaithersburg, MD) was added to $500 \mu \mathrm{g} / \mathrm{ml}$. Established lines were thereafter maintained with $\mathrm{G} 418$ at $250 \mu \mathrm{g} / \mathrm{ml}$. Two days prior to harvest, cells were seeded simultaneously for electrophysiology, RNA preparation, and protein analysis. On the day that the electrophysiology was done, parallel cultures were harvested for RNA and protein analyses.

$R N A$ analysis. In order to isolate total RNA, cells were removed from two T-25 flasks with versene and pelleted in a $50 \mathrm{ml}$ conical centrifuge tube. The cell pellet was rapidly vortexed in $1 \mathrm{ml}$ of $4 \mathrm{M}$ guanidinium thiocyanate and processed under acidic conditions to yield total RNA free from DNA (Chomczynski and Sacchi, 1987). RNA concentrations were determined by A260 optical density measurements done in duplicate. RNase protection assays were performed on 2.5 or $10 \mu \mathrm{g}$ of total RNA according to methods in Ausubel et al. (1991). Riboprobes were synthesized in the presence of ${ }^{32} \mathrm{P}$-UTP to a specific activity of $4 \times 10^{7}$ $\mathrm{cpm} / \mu \mathrm{g}$ cRNA; $2.5 \times 10^{\mathrm{s}} \mathrm{cpm}$ was added to each sample for hybridization. The hybridization mix was incubated at $50^{\circ} \mathrm{C}$ overnight, digested with RNase $A$ and RNase $T 1$, phenol extracted, concentrated, and separated on a denaturing $6 \%$ acrylamide sequencing gel. The amount of RNA protected in each sample was quantified by PhosphorImager analysis using the Molecular Dynamics scanner at the Fred Hutchinson Cancer Research Center, Image Analysis Laboratory, Seattle, WA.

Protein analysis. For both total protein (Western) blot analysis and immunoprecipitation experiments, cells were incubated in equal volumes of culture medium for $20 \mathrm{hr}$, one without radioactivity for Westerns and one containing $0.1 \mathrm{mCi} / \mathrm{ml}^{35} \mathrm{~S}$-methionine for immunoprecipitation. Cells were then rinsed in culture medium several times, removed by versene treatment, and pelleted in a $50 \mathrm{ml}$ conical. The pellet was resuspended in $1 \mathrm{ml}$ of Tris-saline (TBS; $20 \mathrm{~mm}$ Tris- $\mathrm{HCl}$, $100 \mathrm{~mm} \mathrm{NaCl}, \mathrm{pH} \mathrm{7.5)}$ and disrupted in a glass-glass homogenizer. The membrane fraction was separated from the soluble fraction by centrifuging at $15,000 \times g$ for $10 \mathrm{~min}$, and the pellet was resuspended in 1 $\mathrm{ml}$ of $1 \%$ Triton-X in TBS on ice for $1 \mathrm{hr}$. After duplicate resuspensions and centrifugations at $15,000 \times g$ for $30 \mathrm{~min}\left(4^{\circ} \mathrm{C}\right)$, the supernatant was saved as the membrane protein fraction. Total protein concentration was determined in duplicate using the DC Protein Assay kit supplied by Bio-Rad Laboratories (Hercules, CA).

For Western blots, 8-10 $\mu$ g of protein was separated by SDS-PAGE and electrotransferred to either PVDF or nitrocellulose membranes using Protean mini-gel apparati (Bio-Rad). The protein blots were incubated first with polyclonal antibodies developed against a C-terminal peptide of mKv1.1 ( $\alpha-\mathrm{Kv} 1.1$; residues 427-495; Wang et al., 1993). The antibody had been adsorption purified twice against an $\mathrm{mKv} 1.2$-glutathionine-S-transferase fusion protein-coupled sepharose column. (The $\mathrm{mKV} 1.2$ clone is a closely related Shaker-like channcl with high scquence homology; this step was used to make the antibody more specific.) The secondary antibody for chemiluminescence was alkaline phosphatase-conjugated goat anti-rabbit IgG, and for color reactions was horseradish peroxidase-conjugated goat anti-rabbit IgG. The substrate for the chemiluminescent reaction was Lumi-Phos 530 (Boehringer Mannheim Corporation, Indianapolis, IN), and for the color reaction was 3,3'-diaminobenzidine. The Western blot images were densitized and analyzed at the Fred Hutchinson Cancer Research Center, Image Analysis Laboratory.

For immunoprecipitation experiments, either $20 \mu \mathrm{g}$ protein/cell line or $7 \times 10^{6} \mathrm{cpm} / \mathrm{cell}$ line was precleared by incubation with $3 \mu \mathrm{l}$ of preimmune serum for $1 \mathrm{hr}$ at $4^{\circ} \mathrm{C}$ followed by addition of $30 \mu \mathrm{l}$ of Protein A-sepharose ( $2 \mathrm{mg}$ Protein $\mathrm{A} / \mathrm{ml}$ sepharose) in dilution buffer ( $0.1 \%$ bovine hemoglobin and $0.1 \%$ Triton- $X$ in TBS), incubation for $30 \mathrm{~min}$ at $4^{\circ} \mathrm{C}$, and then centrifugation at $5000 \times \mathrm{g}$ for $5 \mathrm{~min}$. Protein was immunoprecipitated by replacing preimmune serum with $3 \mu \mathrm{l}$ of adsorption-purified $\alpha$-Kvl.1 antibody in the same protocol, with the exception that $10 \mu \mathrm{l}$ of Protein A-sepharose was used. Precipitated protein was washed with dilution buffer three times, twice with TBS, and once with $0.5 \mathrm{M}$ Tris, pH $6.8 ; 25 \mu \mathrm{l}$ of $5 \times$ sample buffer was added, and the samples were boiled for $10 \mathrm{~min}$ and separated using 10\% SDSPAGE. The gel was soaked in fluorography enhancing solution (Entensify, Amersham Corporation, Arlington Heights, IL) and dried on 3 $\mathrm{mm}$ filter paper. Blots were placed in a phosphorimager cassette for 5 d, and the image was collected and analyzed at the Fred Hutchinson Cancer Research Center.

Electrophysiology. $\mathrm{CHO}$ cells were grown in adherent culture at low density (5-10\% confluency) on $35 \mathrm{~mm}$ plastic tissue culture dishes. For recording, a Sylgard (Dow Chemical, Midland, MI) chamber was constructed inside the dish, such that the total bath volume was $0.2 \mathrm{ml}$. Perfusion of the bath was achieved by continuous gravity flow, and changes in the perfusion solution were made by switching a four-way valve. The approximate dead volume between solutions was $0.3 \mathrm{ml}$, and the bath flow was approximately $0.5 \mathrm{ml} / \mathrm{min}$. Pipette solution was (mM) K-aspartate, $100 ; \mathrm{KCl}, 20 ; \mathrm{MgCl}_{2}, 3 ; \mathrm{K}_{2}$ EGTA, 10; K ${ }_{2}$ HEPES, 25; ATP, 0.3; GTP, 0.1; pH 7.4 with KOH. Standard bath Ringer solution was (mM) NaCl, $140 ; \mathrm{KCl}, 2.5 ; \mathrm{CaCl}_{2}, 3 ; \mathrm{MgCl}_{2}, 1 ; \mathrm{Na}_{2}$ HEPES, $10 ; \mathrm{pH} 7.4$ with $\mathrm{NaOH}$. For $0 \mathrm{Na}$ experiments the $\mathrm{NaCl}$ was replaced by equimolar $N$-methyl-D-glucamine (NMDG), and $\mathrm{HCl}$ was used for titration. For experiments with increased $\mathrm{K}, \mathrm{NaCl}$ or NMDG was replaced by equimolar $\mathrm{KCl}$. All experiments were corrected for junction potentials, which were $-18 \mathrm{mV}$ for the NMDG solution and $-10 \mathrm{mV}$ for the Ringer solution. For most experiments with standard bath Ringer solution, $1 \mu \mathrm{M}$ tetrodotoxin was added to the solution to block the endogenous Na' current in the CHO cells. Most reagent salts and pharmacological blockers were obtained from Sigma. Fraction I of dendrotoxin (DTX-I) was purified by HPLC as in Newitt et al. (1991).

The whole-cell variation of the patch-clamp technique was used to record $\mathrm{mKv} 1.1 \mathrm{~K}^{+}$currents (Hamill et al., 1981). Recording pipettes were constructed using a two-pull procedure from VWR micropipette 

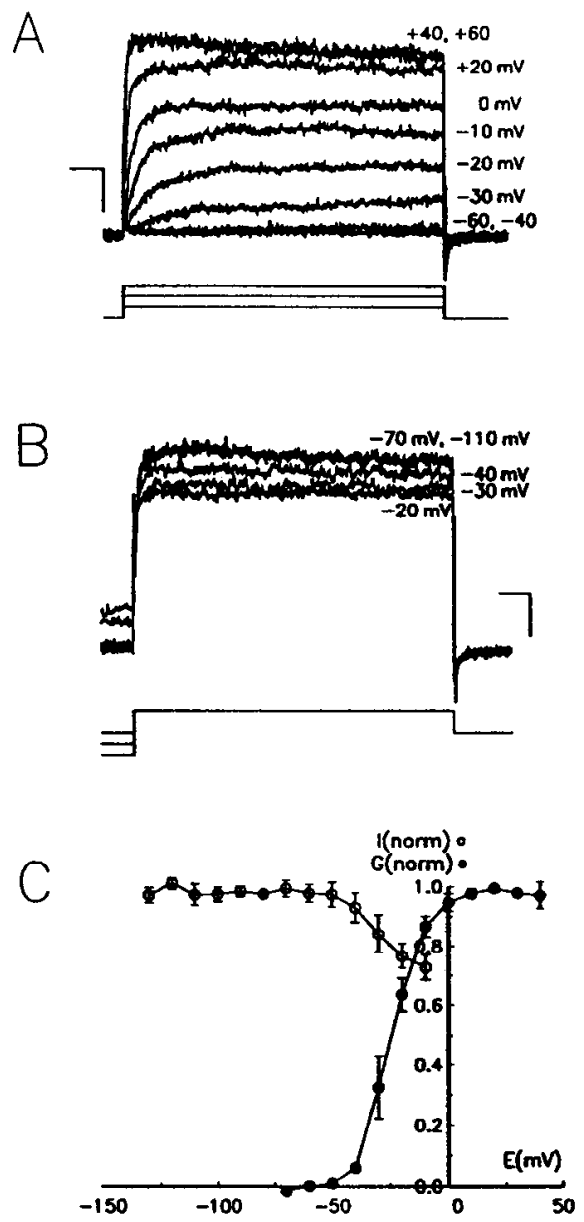

Figure 1. Activation and inactivation of $\mathrm{mKvl} .1$ currents expressed in $\mathrm{CHO} / \mathrm{MK} 1$ cells. $A$, Currents recorded from a holding potential of $-90 \mathrm{mV}$, during potential steps to -60 through $+60 \mathrm{mV}$, as indicated next to the traces. $B$, Steady-state inactivation of currents from same cell. The holding potential was changed from $-110 \mathrm{mV}$ to $-20 \mathrm{mV}$ for $7.5 \mathrm{sec}$ before a step to $+30 \mathrm{mV}$ to elicit the currents shown here. Calibration: $50 \mathrm{msec}, 50 \mathrm{pA}$ (for $A$ and $B$ ). $C$. Resultant conductancevoltage curves from data in $A$ (solid circles) and steady-state inactivation curve from data in $B$ (open circles).

glass $(75 \mu \mathrm{l})$. Dishes were mounted on the stage of a Nikon Diaphot microscope, and pipette manipulation was achieved using a Newport (Fountain Valley, CA) XYZ translator (with one motorized dimension) mounted on a holder for the Orbital Stage (Meridian Instruments, Kent, WA). Currents and voltages were recorded using an Axopatch 200 (Axon Instruments, Burlingame, $\mathrm{CA}$ ), and currents were sampled on line and voltages delivered using an Atari STE computer, ITC16 interface board, and M2Lab softwarc (Instrutcch, Elmont, NY). Current traces were not leak subtracted.

\section{Results}

\section{Electrophysiological and pharmacological characteristics of $m K v 1.1$}

Outward potassium currents in $\mathrm{CHO} / \mathrm{MK} 1$ cells were recorded using a paradigm of stepping from a potential of $-90 \mathrm{mV}$ to between -60 and $+60 \mathrm{mV}$ for $500 \mathrm{msec}$. Current began to activate between -40 and $-30 \mathrm{mV}$, and reached a maximum at $+40 \mathrm{mV}$ (Fig. 1A). The activation time constant decreased with depolarization and ranged from $36 \mathrm{msec}$ at $-20 \mathrm{mV}$ to 6 msec at $+20 \mathrm{mV}$ (mean of four cells). The mKv1.1 current inactivated little, although at the most positive potentials there was $5-8 \%$ inactivation at the end of the $500 \mathrm{msec}$ pulse. The

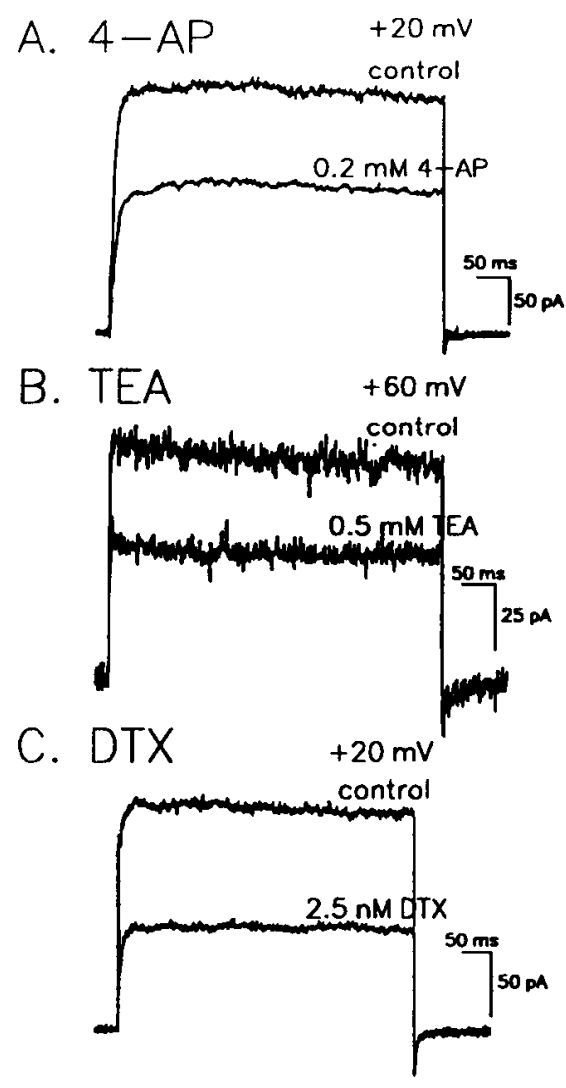

Figure 2. Pharmacology of block of mKv1.1 currents recorded from different cells. $A$, Block by $0.2 \mathrm{~mm}$ 4-AP during a step to $+20 \mathrm{mV}$ from a holding potential of $-70 \mathrm{mV} . B$, Block by $0.5 \mathrm{~mm}$ TEA during a step to $+60 \mathrm{mV}$ from a holding potential of $-90 \mathrm{mV}$. $C$, Block by $2.5 \mathrm{nM}$ DTX during a step to $+20 \mathrm{mV}$ from a holding potential of $-70 \mathrm{mV}$.

steady-state conductance was derived by dividing the average current over the last $30 \mathrm{msec}$ of the pulse by the driving force $\left(E-E_{\mathrm{K}}\right)$, and plotted in a conductance-voltage curve (Fig. $1 C$; $n=5$ ). The curve can be fit by a Boltzmann function with a half-maximal voltage of $-24.9( \pm 2.6) \mathrm{mV}$; the conductance changes $e$-fold in $6.3( \pm 0.5) \mathrm{mV}$.

The steady-state inactivation curve was constructed by varying the holding potential of the cell for $7.5 \mathrm{sec}$ and stepping from that potential to $+30 \mathrm{mV}$ to activate the remaining current (Fig. 1B). A plot of this data (Fig. $1 C ; n=5$ ) shows that negative to $-50 \mathrm{mV}$, no steady-state inactivation is seen. The maximal inactivation measured was $26 \%$ of the total current, from a holding potential of $-10 \mathrm{mV}$, where considerable current is activated. This is consistent with the minimal degree of inactivation seen during $500 \mathrm{msec}$ test pulses with $\mathrm{mKv} 1.1$ (Fig. $1 A)$.

We have studied the sensitivity of $\mathrm{mKv} 1.1$ expressed in $\mathrm{CHO}$ cells to several $\mathrm{K}$ channel blockers (Fig. 2). The block by 4-aminopyridine (4-AP) was half-maximal at $0.35 \mathrm{~mm}(n=15)$. $\Lambda t$ higher concentrations of 4-AP $(2-10 \mathrm{~mm})$ an increase in leak was seen, and the effects of the 4-AP were difficult to reverse. Block by tetraethylammonium (TEA) was half-maximal at 0.5 mM (fit of $n=7$ cells). DTX-I, a snake toxin, has been used as a biochemical probe to identify $K$ channels from a variety of tissues as well as to purify $\mathrm{K}$ channels from mammalian brain (Rehm et al., 1989; Newitt et al., 1991). DTX-I was tested for its blocking effects on $\mathrm{mKv} 1.1$ channels and was shown to block 

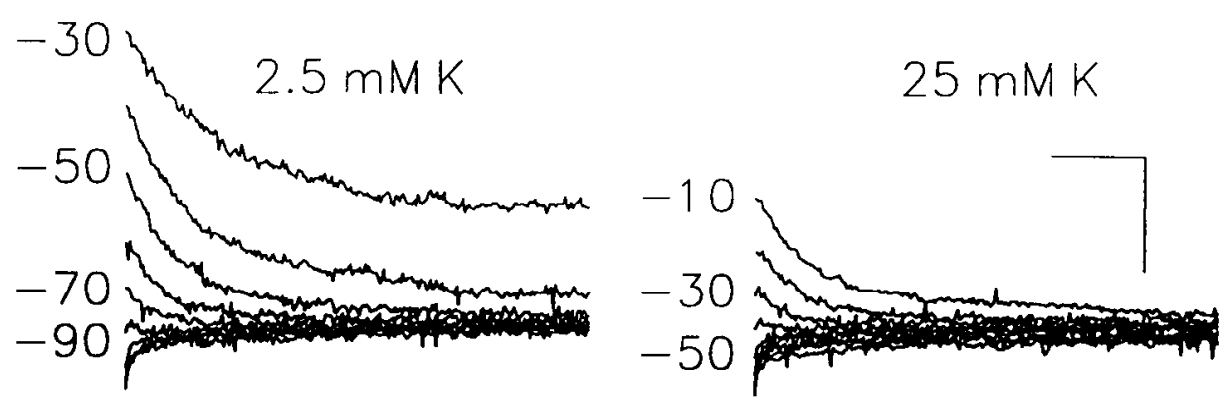

Figure 3. The reversal potential of the tail currents changes with changes in external $\mathrm{K}^{+}$. At the left are tail currents recorded during a potential step to the voltages indicated after a step to +30 $\mathrm{mV}$ to elicit current. External solution contained $2.5 \mathrm{mM} \mathrm{K}^{+}$; current reverses from inward to outward between -80 and $-90 \mathrm{mV}$. At the right are tail currents from the same cell, after external solution was changed to one containing $25 \mathrm{~mm} \mathrm{~K}^{+}$. Tail current reverses from outward to inward between -30 and $-40 \mathrm{mV}$. Calibration: $10 \mathrm{pA}, 10 \mathrm{msec}$. reversibly, with a half-maximal value of about $2.5 \mathrm{nM}$ (fit of $n$ $=10$ cells). At higher concentrations (25-50 nM), washing for approximately $30 \mathrm{~min}$ did not reverse the block by DTX-I.

The ionic selectivity of $\mathrm{mKv1.1}$ was tested. Figure 3 shows tail current traces obtained after a pulse to $+30 \mathrm{mV}$ to elicit current, returning to potentials ranging from -110 to $-20 \mathrm{mV}$. The left panel shows the tail currents in $2.5 \mathrm{~mm}$ external $\mathrm{K}$, under which conditions the current reverses at $-85 \mathrm{mV}$. In the same cell, the external $\mathrm{K}$ was raised to $25 \mathrm{~mm}$, causing the currents to reverse at $-35 \mathrm{mV}$. Three cells were tested in a similar manner, and the mean change was $49 \mathrm{mV}$, which is close to a shift of $57 \mathrm{mV}$ that would be expected for an ideal $\mathrm{K}^{+}$ionselective conductance.

\section{Comparison of $\mathrm{CHO} / \mathrm{MK} 1$ and $\mathrm{CHO} / \mathrm{AB}^{-} / \mathrm{MK} 1$ cells}

The $\mathrm{CHO} / \mathrm{AB}^{-}$cell line was transfected with a plasmid encoding a mutant regulatory subunit of PKA that does not bind cAMP, and remains bound to the catalytic subunit (Clegg et al., 1987). The cAMP-stimulated PKA activity in this $\mathrm{CHO} / \mathrm{AB}^{-}$cell line was less than $10 \%$ of that observed in parental CHO cells without the mutant subunit (Li et al., 1992). A similar reduction of endogenous PKA activity has been observed in other cell lines expressing the same mutant regulatory subunit construct (Ginty et al., 1991; Schecterson and McKnight, 1991).

Cells containing both the mutant regulatory subunit and mKv 1.1 plasmids (CHO/AB-/MK1) expressed greater mKv 1.1 $\mathrm{K}^{+}$current density than cells without the mutant regulatory subunit (CHO/MK1). However, the electrophysiological characteristics of the current were the same between the two groups of cells. Figure $4 A$ shows the conductance-voltage curves for the two types of cells, with the $\mathrm{CHO} / \mathrm{MK} 1$ values shown as circles and the $\mathrm{CHO} / \mathrm{AB}^{-} / \mathrm{MK} 1$ values as triangles. The two curves were not significantly different; similar or greater shifts were observed within the same experimental group of cell lines as between different groups.

Figure $4 B$ shows the amount of current density present in each of three $\mathrm{CHO} / \mathrm{MK} 1$ or $\mathrm{CHO} / \mathrm{AB}^{-/ \mathrm{MK}} 1$ cell lines, and for cell lines containing pZEM plasmid alone (B2, B4). The CHO/ $\mathrm{AB}^{-} / \mathrm{MK} 1$ cells express on average 3.4 times the current density (in $\mathrm{pA} / \mathrm{pF}$ ) that is expressed in $\mathrm{CHO} / \mathrm{MK} 1$ cell lines. All three $\mathrm{CHO} / \mathrm{AB}^{-} / \mathrm{MK} 1$ current densities $(\mathrm{C} 1, \mathrm{C} 9, \mathrm{Cl0})$ were significantly greater than the three $\mathrm{CHO} / \mathrm{MK} 1$ cells $(\mathrm{E} 2, \mathrm{E} 3, \mathrm{E} 4 ; p<$ $0.001)$. Recordings from control cells [CHO (B2) or $\mathrm{CHO}^{-\mathrm{AB}^{-}}$ (B4) cells transfected with control plasmid] showed no outward currents. It is interesting to note that all $\mathrm{CHO} / \mathrm{AB}^{-/} \mathrm{MK} 1$ cell lines had a smaller cell size, averaging $11.5 \pm 3.0 \mathrm{pF}(n=34)$ as compared to $17.0 \pm 4.6 \mathrm{pF}(n=35)$ in the $\mathrm{CHO} / \mathrm{MK} 1$ lines. Furthermore, all cell lines did express a TTX-sensitive sodium current, which was not changed in density between any of the cell lines (data not shown). An additional $\mathrm{CHO} / \mathrm{AB}^{-} / \mathrm{MK} 1$ cell line was recorded under the same conditions and found to express $30.1 \mathrm{pA} / \mathrm{pF}$, increasing the average current density to 26 $\mathrm{pA} / \mathrm{pF}$, a 3.6-fold increase over the $\mathrm{CHO} / \mathrm{MK} 1$ lines. This cell line (C4) was not included in other experiments.
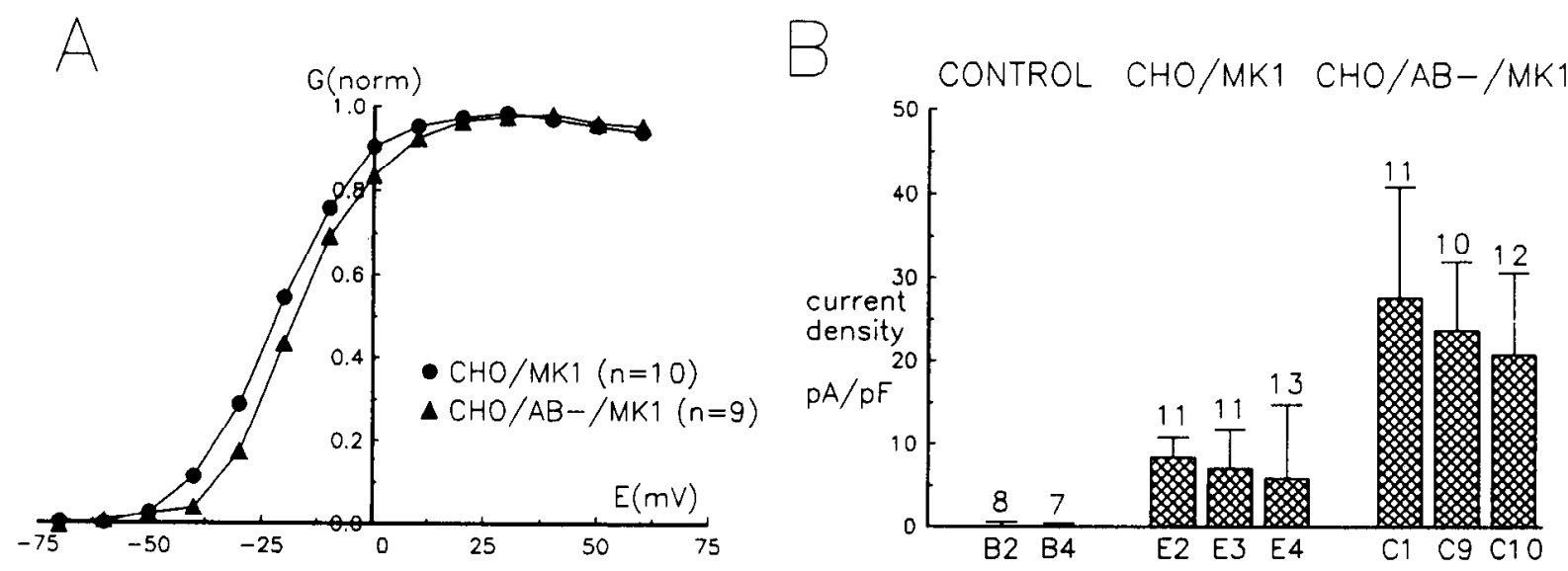

Figure 4. Comparison of currents in $\mathrm{CHO} / \mathrm{MK} 1$ cells and $\mathrm{CHO} / \mathrm{AB}^{-} / \mathrm{MK} 1$ cclls. $A$, Conductance-voltage curves for $\mathrm{CHO} / \mathrm{MK} 1$ cells (circles; $n$ $=10)$ and $\mathrm{CHO} / \mathrm{AB}^{-} / \mathrm{MK} 1$ cells (triangles; $\left.n=9\right) . B$, Histogram of current densities $(\mathrm{pA} / \mathrm{pF})$ from three CHO/MK1 cell lines $(\mathrm{E} 2$, E3, E4) and three $\mathrm{CHO} / \mathrm{AB}^{-} / \mathrm{MK} 1$ cell lines $(\mathrm{Cl}, \mathrm{C} 9, \mathrm{Cl})$. Error bars indicate $\mathrm{SD}$, and numbers above error bars are number of cells from each cell line. The average current density for the $\mathrm{CHO} / \mathrm{MK} 1$ lines was $7.1 \mathrm{pA} / \mathrm{pF}$, and for the $\mathrm{CHO} / \mathrm{AB}^{-} / \mathrm{MK} 1$ lines was $24.0 \mathrm{pA} / \mathrm{pF}$. 
Figure 5. RNase protection assays. A, Digitized phosphorimager scan of the gel of an RNase protection assay run with the $5^{\prime}$ riboprobe is shown in the upper panel. The lower panel is a histogram of the scan. $B 2$ is a control cell line in which the pZEM vector without the $\mathrm{mKv} 1.1$ insert was transfected into wild-type $\mathrm{CHO}$ cell lines; $B 4$ is the $\mathrm{CHO} / \mathrm{AB}^{-}$cell line with the same vector construct. $E 2, E 3$, and $E 4$ are $\mathrm{CHO} /$ MK1 cell lines. $C l, C 9$, and $C 10$ are $\mathrm{CHO} / \mathrm{AB}^{-} / \mathrm{MK} 1$ cell lines. The undigested probe is shown (far left lane), as well as a tRNA control. The image is quantified as shown on the histogram below. The two values on the far right indicate the average normalized intensities of the signal for the five RNase protections assays that were quantified. Averaged CHO/MK1 (E lines) was 1.00 $\pm 0.22(n=14$ lanes) and averaged $\mathrm{CHO} / \mathrm{AB}^{-} / \mathrm{MK} 1$ (C lines) was $1.94 \pm$ 0.57 ( $n=13$ lanes). $B$, Diagram of the pZEM-mKv1.1 plasmid construct used for transfection. The positions of the $5^{\prime}$ and $3^{\prime}$ riboprobes are indicated by bars above. $M T-1$ indicates the mouse metallothionine promoter.
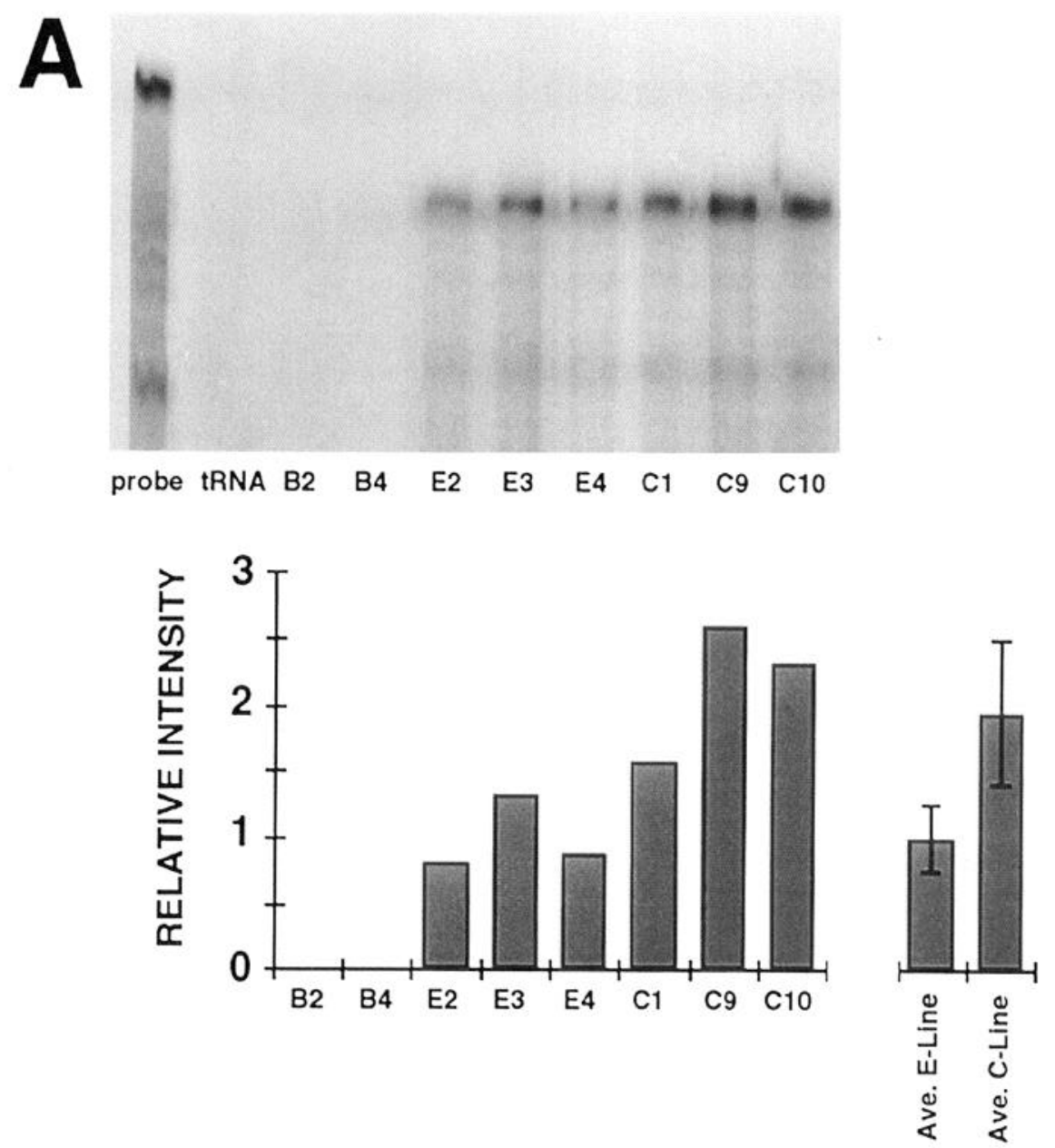

$B$

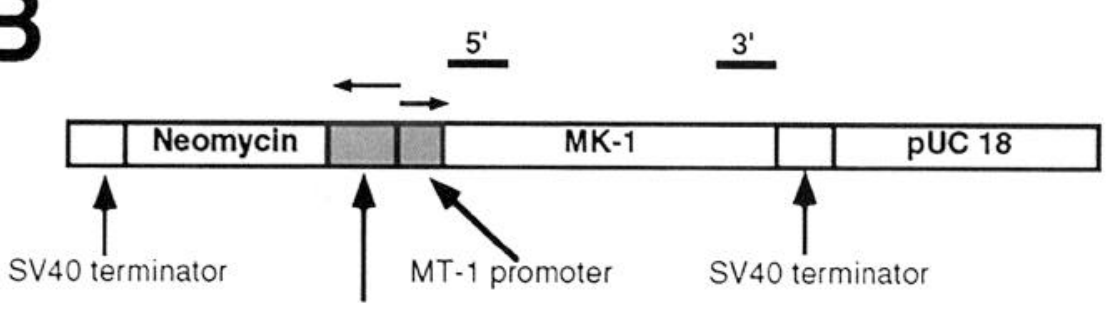

SV40 early promoter

\section{RNase protection assays}

Seven sets of RNase protection assays were performed. Results from an experiment using the $5^{\prime}$ probe (see Fig. $5 B$ for plasmid structure) are shown in Figure 5. An assay using the $3^{\prime}$ probe gave similar results (data not shown). Figure $5 A$ shows that no mKv1.1-specific protected fragment was detected using the 5' probe to examine the control cell lines B2 (CHO with pZEM alone) or $\mathrm{B} 4\left(\mathrm{CHO} / \mathrm{AB}^{-}\right.$with pZEM alone). Additional control cell lines transfected with pZEM containing mKv1.1 in the antisense orientation showed no mKv1.1 mRNA expression (data not shown). In contrast, an $\mathrm{mKv} 1.1$-specific protected fragment was detected using either the $5^{\prime}$ or the $3^{\prime}$ probe to examine all six cell lines expressing mKv1.1 (Fig. $5 A$ ). The three CHO/MK1 lines (E2, E3, and E4) have a lower level of specific mRNA expression, as determined by relative intensity on a phosphor- imager scan, than the corresponding $\mathrm{CHO} / \mathrm{AB}^{-} / \mathrm{MK} 1$ cell lines $\mathrm{C} 1, \mathrm{C} 9$, and $\mathrm{C10}$. Five of the seven RNase protection assays were quantitated by phosphorimaging analysis. In three of these assays we also quantified the levels of 18S RNA, expressing mKv1.1 RNA relative to $18 \mathrm{~S}$ RNA levels. The average increase in $\mathrm{mKv} 1.1$-specific $\mathrm{RNA}$ in the $\mathrm{CHO} / \mathrm{AB}^{-} / \mathrm{MK} 1$ lines relative to the $\mathrm{CHO} / \mathrm{MK} 1$ lines was $1.94 \pm 0.57(p<0.001)$. These results indicate that, at steady state, there is an increased level of mKv1.1 RNA in the cells containing the mutant regulatory subunit. This does not appear to be a general feature of RNA expression in these cells, as the RNA levels for $18 \mathrm{~S}$ are not significantly different between the two cell types (average 18S density of $C$ lines relative to $E$ lines was $1.045, n=2$ ). We do not know if this increase in steady-state mKv1.1 transcript levels is the result of changes in transcription rates or stability of the RNA (see Discussion). 


\section{mKv1.1 protein levels}

The 3.4-fold increase in mKv1.1 current levels in the $\mathrm{CHO} /$ $\mathrm{AB}^{-} / \mathrm{MK} 1$ cells ( $\mathrm{C}$ lines) over the $\mathrm{CHO} / \mathrm{MK} 1$ cells (E lines) cannot be accounted for by taking only the twofold increase in mKv1.1 RNA transcript into consideration. In order to explore further the mechanisms involved in upregulation of $m K v 1.1$ current in cells expressing the mutant regulatory subunit of PKA, protein levels of $\mathrm{mKv} 1.1$ were assessed using a polyclonal antisera specific to mKv1.1 ( $\alpha$-Kv1.1; Wang et al., 1993). Figure $6 A$ shows an immunoblot (Western) in which total membrane protein from the indicated cell lines was probed with $\alpha$-Kv1.1. A single major band of $55-65 \mathrm{kDa}$ is detected first in the $\mathrm{CHO}$ / MK1 (E2, E3) and more strongly in the $\mathrm{CHO} / \mathrm{AB}^{-} / \mathrm{MK} 1$ cell lines $(\mathrm{C} 1, \mathrm{C} 9)$. The size of the recognized protein is somewhat larger than the predicted molecular weight of the unglycosylated mKv1.1 protein $(56.4 \mathrm{kDa}$; Tempel et al., 1988), suggesting that some glycosylation has occurred in the $\mathrm{CHO}$ cell lines. The band was not detected by preimmune sera or when $\alpha-\mathrm{Kv} 1.1$ sera were preincubated with $\mathrm{mKv} 1.1$ peptide (data not shown), indicating that $\alpha-\mathrm{Kv} 1.1$ specifically detects the expressed $\mathrm{mKv} 1.1$ protein. Staining intensity of the $60 \mathrm{kDa}$ region in each lane was measured by chemiluminescent detection and densitometric scanning; the results are graphed below the gel. Six such Western blots were analyzed. On average, the $\mathrm{CHO} / \mathrm{AB}^{-} / \mathrm{MK} 1$ cell lines (C lines) have a 2.8 -fold increase in protein compared to the $\mathrm{CHO} / \mathrm{MK} 1$ cell lines (E lines; $p<0.001$ ). The control cell lines, which are transfected with the pZEM plasmid only, showed no detectable $\mathrm{mKv} 1.1$ protein expression, consistent with their lack of $\mathrm{mKv} 1.1$ current.

Immunoprecipitation experiments on metabolically labeled cells confirmed the finding that $\mathrm{mKvl} .1$ protein levels were increased in $\mathrm{CHO} / \mathrm{AB}^{-} / \mathrm{MK} 1$ cell lines (Fig. $6 \mathrm{~B}$ ). Control and MK1-expressing cell lines were metabolically labeled with ${ }^{35} \mathrm{~S}$ methionine for $20 \mathrm{hr}$, harvested, and immunoprecipitated with $\alpha-K v 1.1$. Precipitated proteins were separated by SDS-PAGE and analyzed by phosphorimaging. Consistent with the Western immunoblot data, the presumed $\mathrm{mKv} 1.1$ band appeared in all lines transfected with $\mathrm{mKv1.1}$, was increased an average of 3.0fold in the $\mathrm{CHO} / \mathrm{AB}^{-} / \mathrm{MK} 1$ lines $(p<0.001, n=6)$, but was not detectable in cell lines transfected with control plasmid only. Quantitatively comparable data was obtained when the metabolically labeled samples were independently analyzed by Western blot, indicating that steady-state levels of $\mathrm{mKv} 1.1$ protein were reached during the labeling period (data not shown). Thus, chronic inhibition of PKA activity leads to a significant increase in mKvl.1 protein assayed either by immunoblot or by immunoprecipitation.

\section{Discussion}

Using whole-cell recording techniques, we have observed that expression of the mKvl.1 K channel gene in transfected $\mathrm{CHO}$ cells gives rise to a rapidly activating, sustained $\mathrm{K}^{+}$current that activates at $-40 \mathrm{mV}$ and is sensitive to block by 4-AP, TEA, and DTX. These physiological and pharmacological characteristics are similar to those observed for $\mathrm{rKv} 1.1$, the rat homolog of $\mathrm{mKv} 1.1$, when it is expressed transiently in Xenopus oocytes (Stuehmer et al., 1988). We also found that, in CHO cells, coexpression of $\mathrm{mKv} 1.1$ with a plasmid encoding a dominant negative mutation of the regulatory subunit of $\mathrm{PKA}\left(\mathrm{AB}^{-}\right)$causes an increase in $\mathrm{mKvl} .1 \mathrm{~K}^{+}$current density. Significant increases are seen in both mKv1.1 RNA levels and protein levels.
These results suggest that the increased $\mathrm{K}^{+}$current seen in the $\mathrm{CHO} / \mathrm{AB}^{-} / \mathrm{MK}^{\prime}$ cell lines relative to the $\mathrm{CHO} / \mathrm{MK} 1$ cell lines occurs by mechanisms that are posttranscriptional and may include regulation of RNA levels. These findings are distinct from the results of comparable studies on PKA regulation of $\mathrm{Na}$ channel expression (Ginty et al., 1992; Li et al., 1992).

Several mechanisms might give rise to an increased current in the PKA-deficient cell lines. It is unlikely that PKA is affecting mKv1.1 gene transcription in our system. While PKA has been shown to regulate transcription of various genes through the transcription factor CREB (Montminy et al., 1989; Habener, 1990), in our transformed CHO cell system, mKvl.1 expression is driven by the PKA-insensitive metallothionine-1 promoter in the ZEM plasmid. The $\mathrm{mKv} 1.1$ gene endogenous to the $\mathrm{CHO}$ cell genome is apparently also insensitive to changes in PKA activity, as there was no induction of mKv1.1 current in $\mathrm{CHO}$ cells where PKA activity was decreased in cells containing the plasmid control vector without the mKvl.1 insert (CHO/AB line B4). Thus, the upregulation of mKv1.1 RNA is more likely to occur by modification of PKA-sensitive gene products that may be involved in the processing, modification, or stabilization of functional mKv1.1 RNA. Several examples of second messenger modulation of mRNA have been reported. In a rat hepatoma cell line, dibutyryl-cAMP increases the half-life of mRNA for phosphoenolpyruvate carboxykinase by 10 -fold, via a mechanism that does not require protein synthesis and that enhances the stability of the polysome-free mRNA (Hua and Hod, 1992). In a cell line expressing corticotropin-releasing hormone, stimulation of protein kinase $\mathrm{C}$ by phorbol esters increases mRNA levels for this hormone, and also increases the length of the polyA tail of the mRNA by threefold (Adler et al., 1992), thus leading to a possible increase in mRNA stability due to an increased ability to bind to the polyA binding protein and protection from exonucleolytic digestion (Bernstein and Ross, 1989; Bernstein et al., 1989). Although we do not know the specific mechanism by which mKv1.1 RNA is increased in our system, it is unlikely that this increase alone (1.9-fold) could entirely account for the increase seen in current densities (3.4-fold) or protein levels (2.8-fold).

It remains possible that some portion of the increase in $\mathrm{mKv} 1.1$ current density is determined by PKA during translation, assembly, insertion, or function of the $\mathrm{mKv} 1.1$ channels. Phosphorylation of $\mathrm{Na}$ channels in excised patches using cAMP and PKA catalytic subunit causes a decrease in the $\mathrm{Na}^{+}$current $(\mathrm{Li}$ et al., 1992). In addition, using a strategy similar to the one used in the present study, coexpression of the mutant regulatory subunit of PKA in CHO cells causes upregulation of $\mathrm{Na}^{+}$current, suggesting that the endogenous level of PKA activity in $\mathrm{CHO}$ cells is sufficient to modulate the level of $\mathrm{Na}$ channel expression. Unlike the situation with $\mathrm{mKv} 1.1 \mathrm{~K}$ channels, $\mathrm{Na}$ channel mRNA levels are unchanged while $\mathrm{Na}$ channel-specific saxitoxin (STX) binding sites on the cell surface increase when PKA activity is reduced. These data suggest that inhibition of PKA causes Na channel number and current to increase via an unknown posttranscriptional mechanism (Li et al., 1992). In contrast, hormonally induced PKA activity in differentiating $\mathrm{PCl} 2$ cells causes an increase in $\mathrm{Na}^{+}$current (Kalman et al., 1990). Recent studies (Ginty et al., 1992) indicate that this upregulation requires PKA activity at the posttranslational level: PC12 cells transfected with a mutant regulatory subunit of PKA respond to hormone by relatively normal morphological differentiation, by increasing Na channel mRNA, and by increasing the number 

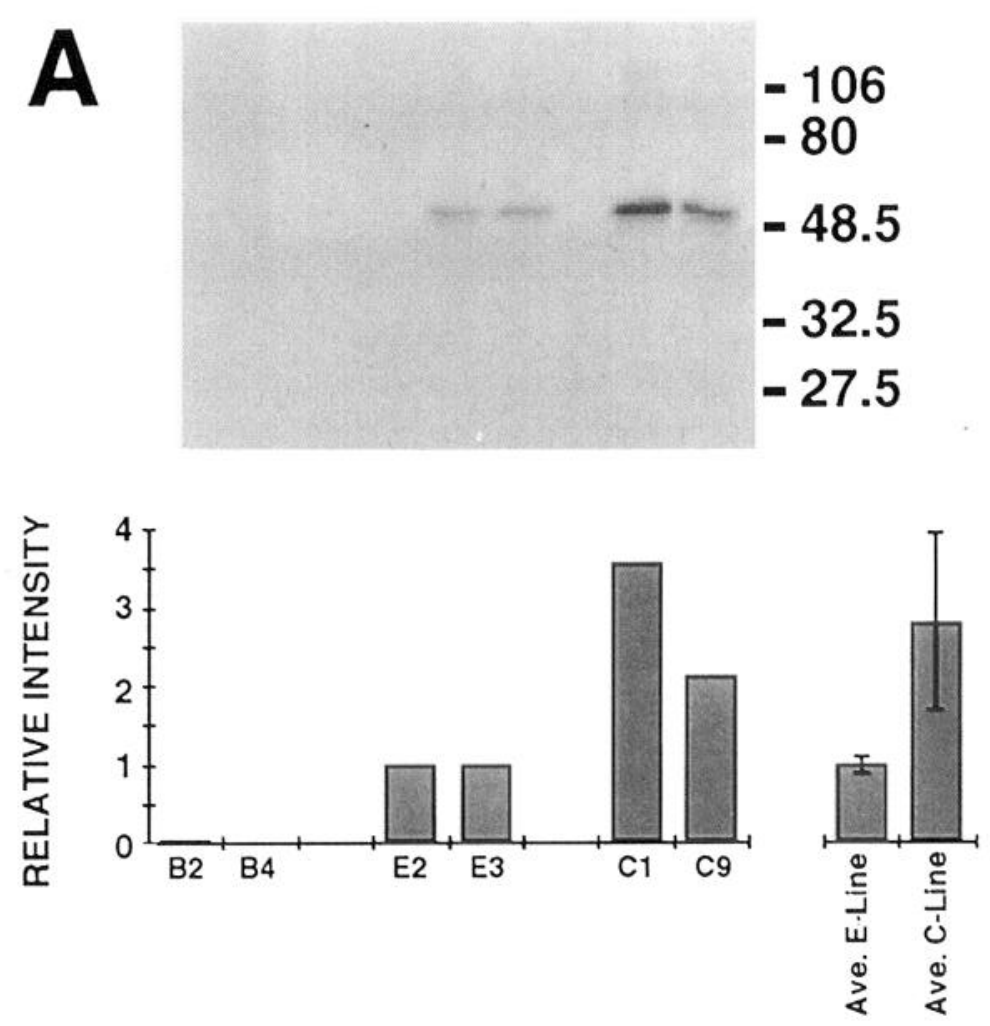

Figure 6. Analysis of $\mathrm{mKv} 1.1$ protein levels. $A$, Total membrane protein (Western) gel demonstrating that the $\mathrm{CHO} / \mathrm{AB}^{-} / \mathrm{MK} 1$ lines $(C 1, C 9)$ express more mKv1.1-specific antibody-labeled protein than does the $\mathrm{CHO} / \mathrm{MK} 1$ line $(E 2, E 3), B 2$ and $B 4$ are control cell lines (as in Fig. 5). Averaged normalized intensities for the six Western blots of $\mathrm{CHO} / \mathrm{MK} 1$ (E lines) were 1.00 \pm 0.09 ( $n=12$ lanes), and for the $\mathrm{CHO} /$ $\mathrm{AB}^{-} / \mathrm{MK} 1$ (C lines), were $2.78 \pm 1.20$ ( $n=12$ lanes). $B$, Immunoprecipitation of ${ }^{35} \mathrm{~S}$-methionine-labeled $\mathrm{mKv1.1}$ protein after a $20 \mathrm{hr}$ incubation. E2, E3 and $E 4$ are $\mathrm{CHO} / \mathrm{MK} 1$ cell lines; $C 1$. $C 9$, and $C 10$ are $\mathrm{CHO} / \mathrm{AB}^{-} / \mathrm{MK} 1$ cell lines. All lanes were loaded with $7 \times$ $10^{6} \mathrm{cpm} / \mu \mathrm{g}$ total radioactivity. The $a r$ row indicates the protein labeled at approximately $70 \mathrm{kDa}$.

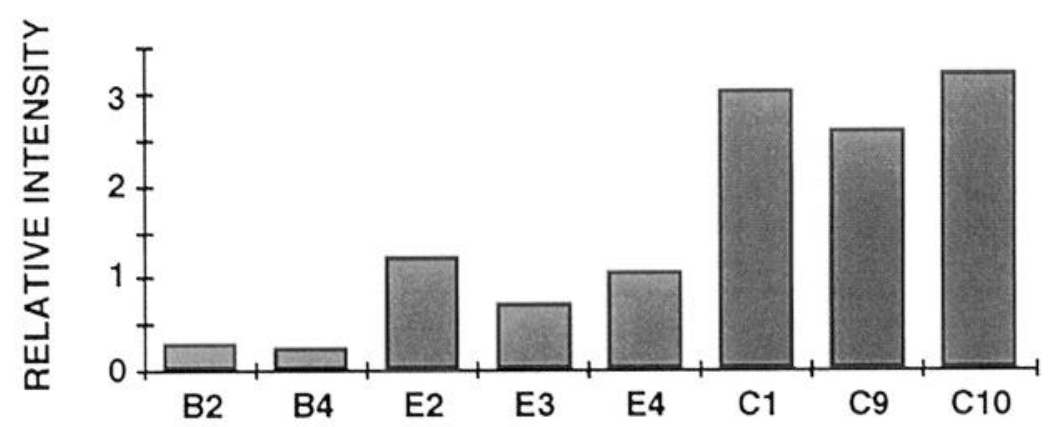


of STX-binding Na channels on the cell surface. However, no significant $\mathrm{Na}^{+}$current is observed in any of the PC12 cells expressing the mutant regulatory subunit of PKA, suggesting that PKA activity is required posttranslationally to establish functional Na channels. Thus, chronic reduction of PKA results in the reduction of $\mathrm{Na}^{+}$current in PC12 cells, an increase in $\mathrm{Na}{ }^{\dagger}$ current in transfected $\mathrm{CHO}$ cells, and a comparable but mechanistically unique increase in $\mathrm{K}^{+}$current in our studies.

In a few cell types, endogenously expressed delayed rectifiertype $\mathrm{K}^{+}$currents have been shown to be functionally modulated by PKA. In human T lymphocytes, stimulation with $\beta$-adrenergic agonists or cAMP directly modulate a $\mathrm{K}^{+}$current, causing a decrease in peak current, an increase in inactivation during the pulse, a decrease in the voltage dependence of steady-state inactivation, and a negative shift in the current-voltage relation (Soliven and Nelson, 1990). This $\mathrm{K}^{+}$current inactivates during a maintained pulse, has a $K_{i}$ for block of TEA of $8-16 \mathrm{~mm}$, and resembles the $n$-type $\mathrm{K}$ channel found in lymphocytes (DeCoursey et al., 1987a). This channel has been identified as MK3 or mKv1.3 (Grissmer et al., 1990; also called RGK5, Douglass et al., 1990), a channel closely related to $\mathrm{mKv}$.1. On a longer time scale, the $n$-type channel has also been shown to be upregulated by mitogenic stimulation in mouse $T$ lymphocyles (DeCoursey et al., 1987b) due, at least in part, to synthesis of new protein. Thus, this $\mathrm{mKv1.1-related} \mathrm{channel} \mathrm{can} \mathrm{be} \mathrm{upregulated}$ developmentally or downregulated when PKA activity is increased acutely. In our experiments, PKA activity was inhibited chronically, resulting in an increase in $\mathrm{mKv} 1.1$ current.

In cardiac tissue, the effect of cAMP and of the catalytic subunit of PKA is to upregulate $\mathrm{K}^{+}$current (Giles et al., 1989; Yakawa and Kameyama, 1990). The molecular species of $\mathrm{K}$ channel modulated by adrenergic input, cAMP, and the catalytic subunit of PKA is not known in heart, and thus the molecular structure of the phosphorylation site is also unknown. It is possible that at least one of the K channels regulated by PKA in heart is not closely related to Shaker or to $\mathrm{mKv1.1}$. Specifically, a small (130 amino acid-encoding) cDNA, min-K, is expressed in cardiac tissue and induces a very slowly activating current, $I_{\mathrm{sK}}$, when expressed in Xenopus oocytes (Folander et al., 1990). The kinetics of activation and deactivation of the min-K-induced current resemble closely those recorded in several types of cardiac cells. Furthermore, the $\mathrm{K}^{+}$current induced by min-K in oocytes is upregulated by PKA stimulation. This PKA stimulation, however, is not affected by a site-directed mutation of the putative PKA phosphorylation site in the expressed min-K cDNA (Blumenthal and Kaczmariek, 1992). Instead, the upregulation seen in oocytes expressing min-K appears to be caused by insertion of new channels into the cell membrane.

We conclude from the literature that, depending on cell type being studied, changing cellular PKA activity can result in either increased or decreased channel expression and that this change can be brought about either directly or indirectly via transcriptional, posttranscriptional, or posttranslational mechanisms. Given the ubiquity of predicted PKA phosphorylation sites on cloned ionic channel proteins, the elucidation of various cellspecific mechanisms involved in PKA regulation of these currents may provide important insights into the observed complexity of cellular signaling. Our results suggest that chronic inhibition of PKA activity in $\mathrm{CHO}$ cells expressing mKv1.1 results in increased $\mathrm{K}$ channel expression at the levels of RNA, protein, and current density. At present we do not know the molecular nature of this regulation. It will be interesting to know whether channel regulation requires direct phosphorylation of the channel protein.

\section{References}

Adler GK, Rosen LB, Fiandaca MJ, Majzoub JA (1992) Protein kinase- $C$ activation increases the quantity and poly $(A)$ tail length of corticotropin-releasing hormone messenger RNA in NPLC cells. Mol Endocrinol 6:476-484.

Ausubel FM, Brent R, Kingston RE, Moore DD, Seidman JG, Smith JA, Struhl K (1991) Current protocols in molecular biology. New York: Wiley.

Baumann A, Grupe A, Ackermann A, Pongs O (1988) Structure of the voltage dependent potassium channel is highly conserved from Drosophila to vertebrate central nervous system. EMBO J 7:24572463.

Bernstein P, Ross J (1989) Poly(A), poly(A) binding protein and the regulation of mRNA stability. Trends Biochem Sci 14:373-377.

Bernstein P, Peltz SW, Ross J (1989) The poly(A)-poly(A)-binding protein complex is a major determinant of mRNA stability in vitro. Mol Cell Biol 9:659-670.

Blumenthal EM, Kaczmeriek LK (1992) Modulation by cAMP of a slowly activating potassium channel expressed in Xenopus oocytes. $\mathbf{J}$ Neurosci 12:290-296.

Chandy KG, Williams CB, Spencer RH, Aguilar BA, Ghanshani S, Tempel BL, Gutman GA (1990) A family of three mouse potassium channel genes with intronless coding regions. Science 247:973-975.

Chandy KG, Douglass J, Gutman GA, Jan L, Joho R, Kaczmarek L, MacKinnon D, North RA, Numa S, Ribera A, Rudy B, Salkoff L, Swanson R, Tanouye M, Tempel BL (1991) A simplified nomenclature for vertebrate voltage-gated potassium channel genes. Nature 352:26.

Christie MJ, Adelman JP, Douglass J, North RA (1989) Expression of a cloned rat brain potassium channel in Xenopus oocytes. Science 244:221-224.

Chomczynski P, Sacchi N (1987) Single-step method of RNA isolation by acid guanidinium thiocyanate-phenol-chloroform extraction. Anal Biochem 162:156-159.

Clegg CH, Correll LA, Cadd GG, McKnight GS (1987) Inhibition of intracellular cAMP-dependent protein kinase using mutant genes of the regulatory type I subunit. J Biol Chem 262:13111-13119.

DeCoursey TE, Chandy KG, Gupta S, Cahalan MD (1987a) Two types of potassium channels in murine T lymphocytes. J Gen Physiol 89: 379-404.

DeCoursey TE, Chandy KG, Gupta S, Cahalan MD (1987b) Mitogen induction of ion channels in murine T lymphocytes. J Gen Physiol 89:405-420.

Douglass J, Osborne PB, Cai Y-C, Wilkinson M, Christie MJ, Adelman JP (1990) Characterization and functional expression of a rat genomic DNA clone encoding a lymphocyte $\mathrm{K}^{+}$channel. J Immunol 144:4841-4850.

Drewe JA, Verma S, Frech G, Joho RH (1992) Distinct spatial and temporal expression patterns of $\mathrm{K}^{+}$channel mRNAs from different subfamilies. J Neurosci 12:538-548.

Folander K, Smith JS, Antanavage J, Bennett C, Stein RB, Swanson R (1990) Cloning and expression of the delayed-rectifier $I_{\mathrm{sK}}$ channel from neonatal rat heart and diethylstilbestrol-primed rat uterus. Proc Natl Acad Sci USA 87:2975-2979.

Giles W, Nakajima T, Ono K, Shibata EF (1989) Modulation of a delayed rectifier $\mathrm{K}^{+}$current by isoprenaline in bull-frog atrial myocytes. J Physiol (Lond) 415:233-249.

Ginty DD, Glowacka D, DeFranco C, Wagner JA (1991) Nerve growth factor-induced neuronal differentiation after dominant repression of both type I and type II cAMP-dependent protein kinase activities. J Biol Chem 266:15325-15333.

Ginty DD, Fanger GR, Wagner JA, Maue RA (1992) The activity of cAMP-dependent protein kinase is required at a posttranslational level for induction of voltage-dependent sodium channels by peptide growth factors in PC12 cells. J Cell Biol 116:1465-1473.

Grissmer S, Dethlefs B, Wasmuth J, Goldin AL, Gutman GA, Cahalan MD, Chandy KG (1990) Expression and chromosomal localization of a lymphocyte $\mathrm{K}^{+}$channel gene. Proc Natl Acad Sci USA 87:94119415 .

Habener JF (1990) Cyclic AMP response element binding proteins: a cornucopia of transcription factors. Mol Endocrinol 4:1087-1094. 
Hamill OP, Marty A, Neher E, Sakmann B, Sigworth FJ (1981) Improved patch-clamp technique for high resolution current recording from cells and cell-free membrane patches. Pfluegers Arch 391:85100.

Hopkins WF, Tempel BL (1992) Members of a mouse subfamily of genes encoding voltage-gated potassium channel subunits form heteromultimers when co-expressed in Xenopus oocytes. Soc Neurosci Abstr 18:1093.

Hua J, Hod Y (1992) The role of protein synthesis in the decay of phosphoenolpyruvate carboxykinase messenger RNA. Mol Endocrinol 6:1418-1424.

Jan LY, Jan YN (1989) Voltage-sensitive ion channels. Cell 56:1325.

Kalman D, Wong B, Horvai AE, Cline MJ, O'Laguc PH (1990) Nerve growth factor acts through cAMP-dependent protein kinase to increase the number of sodium channels in PC12 cells. Neuron 4:355366.

Koren G, Liman ER, Logothetis DE, Nadal-Ginard B, Hess P (1990) Gating mechanism of a cloned potassium channel expressed in frog oocytes and mammalian cells. Neuron 2:39-51.

Li M, West JW, Lai Y, Scheuer T, Catterall WA (1992) Functional modulation of brain sodium channels by cAMP-dependent phosphorylation. Neuron 8:1-20.

Mayford M, Barzilai A, Keller F, Schacher S, Kandel ER (1992) Modulation of an NCAM-related adhesion molecule with long-term synaptic plasticity in Aplysia. Science 256:638-644.

Miller C (1991) 1990: annus mirabilis of potassium channels. Science 252:1092-1096.

Montminy MR, Gonzalez GA, Yamamoto KK (1990) Regulation of cAMP-inducible genes by CREB. Trends Neurosci 13:184-188.

Newitt RA, Houamed KM, Rehm H, Tempel BL (1991) Potassium channels and epilepsy: evidence that the epileptogenic toxin, dendro- toxin, binds to potassium channel proteins. Epilepsy Res [Suppl] 4:263273.

Rehm H, Newitt RA, Tempel BL (1989) Immunological evidence for a relationship between the dendrotoxin-binding protein and the mammalian homologue of the Drosophila Shaker $\mathrm{K}^{+}$channel. FEBS Lett 249:224-228.

Roberds SL, Tamkun MM (1991) Cloning and tissue-specific expression of five voltage-gated potassium channel cDNAs expressed in rat heart. Proc Natl Acad Sci USA 88:1798-1802.

Salkoff L, Baker K, Butler A, Covarrubias M, Pak MD, Wei A (1992) An essential 'set' of $\mathrm{K}^{+}$channels conserved in flies, mice and humans. Trends Neurosci 15:161-166.

Schecterson LC, McKnight GS (1991) Role of cyclic adenosine 3',5'monophosphate-dependent protein kinase in hormone-stimulated beta-endorphin secretion in AtT20 cells. Mol Endocrinol 5:170-178.

Soliven B, Nelson DJ (1990) Beta adrenergic modulation of K ${ }^{+}$current in human T lymphocytes. J Membr Biol 117:263-274.

Stuehmer W, Stocker M, Sakmann B, Seeburg P, Baumann A, Grupe A, Pongs O (1988) Potassium channels expressed from rat brain cDNA have delayed rectifier properties. FEBS Lett 242:199-206.

Tempel BL, Jan YN, Jan LY (1988) Cloning of a probable potassium channel gene from mouse brain. Nature 332:837-839.

Trautwein W, Hescheler J (1990) Regulation of cardiac L-type calcium current by phosphorylation and G proteins. Annu Rev Physiol 52: 257-274.

Wang H, Kunkel DD, Martin TM, Schwartzkroin PA, Tempel BL (1993) Heteromultimeric $\mathrm{K}^{+}$channels are located in axonal nodes of Ranvier and in synaptic terminals. Nature, in press.

Yakawa K, Kameyama M (1990) Mechanism of receptor-induced modulation of the delayed outward potassium current in guinea-pig ventricular myocytes. J Physiol (Lond) 421:135-150. 